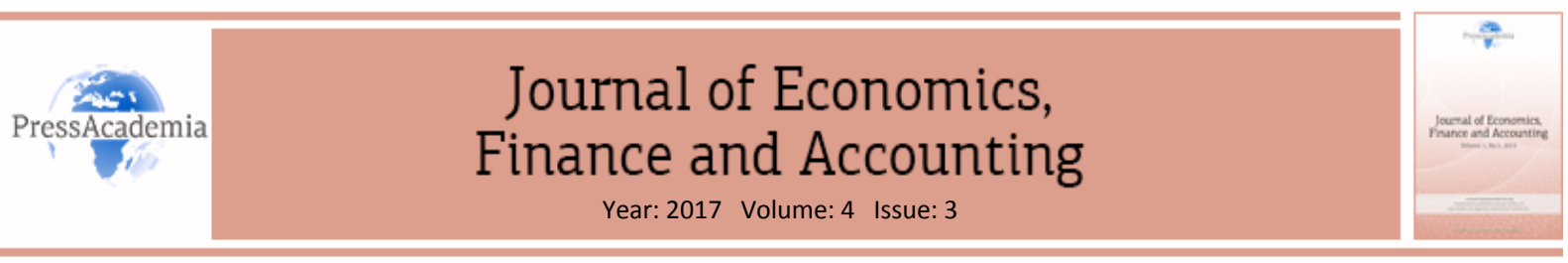

\title{
THE QUALITY OF THE SERVICES OF PROFESSIONAL ACCOUNTANTS, CUSTOMER SATISFACTION, SWICTHING COST AND BEHAVIORAL INTENTIONS
}

\author{
DOI: 10.17261/Pressacademia.2017.698 \\ JEFA- V.4-ISS.3-2017(10)-p.304-315
}

Ismail Atabay ${ }^{1}$, Fatih Koc ${ }^{2}$, Mustafa Melkin Oder ${ }^{3}$, Bayram Alamur ${ }^{4}$

'Balıkesir University, Havran Vocational School, Havran Balıkesir, Turkey. atabay@balikesir.edu.tr

${ }^{2}$ Kocaeli University, Kandıra School of Applied Sciences, Kandıra, Kocaeli, Turkey. fatih.koc@kocaeli.edu.tr

${ }^{3}$ Balıkesir University, Havran Vocational High School, Havran Balıkesir, Turkey. mstfoder@gmail.com

${ }^{4}$ Balıkesir University, Havran Vocational High School, Havran Balıkesir, Turkey. alamur bayram@hotmail.com

\section{To cite this document}

Atabay I., Koc F., Oder M. M. and Alamur B. (2017). The quality of the services of professional accountants, customer satisfaction, swicthing cost and behavioral intentions. Journal of Economics, Finance and Accounting (JEFA), V.4, Iss.3, p.304-315.

Permemant link to this document:http://doi.org/10.17261/Pressacademia.2017.698

Copyright: Published by PressAcademia and limited licenced re-use rights only.

\begin{abstract}
Purpose- This study aims to determine how the income taxpayers who buy services from the members of the accounting profession perceive the quality of service they buy, how the quality perceived affects the customer satisfaction and conversion costs, how the customer satisfaction affects the conversion costs and as well as how the conversion costs affect their behavioral intentions.

Methodolgy- A questionnaire was applied to 1.070 income taxpayers who purchased services from professional accountants in Balıkesir province center and districts and the obtained data were subjected to statistical analysis and the results were interpreted.

Findings- According to the study results, on perceived quality of customer happiness and swicthing costs. It is identified that all dimension of suggestion to others of behavioral intentions and the financial cost dimension of swicthing costs have no effect on the dimension of repurchase of behevioral intentions.

Conclusion- As a result of the study, it is determined that the quality has an effect on the customer satisfaction in same with the literature, and the conversion costs have a high cost in the relationship between the members of accounting profession and businesses . In addition, it is discovered that the factors of conversion costs have an effect on behavioral intention factors.

Keywords: Members of accounting profession, service quality, customer satisfaction, swicthing cost, behavioral intentions JEL Codes: M41, M31, M37
\end{abstract}

\section{MUHASEBE MESLEK MENSUPLARININ SUNDUĞU HIZMETIN KALITESI, MÜŞTERi MEMNUNIYETi, DEĞIŞTIRME MALIYETLERI VE DAVRANIŞSAL NIYETLER ${ }^{1}$}

\section{ÖZET}

Amaç- Bu çalışma, muhasebe meslek mensuplarından hizmet satın alan beyannameli gelir vergisi mükelleflerinin satın aldıkları hizmetin kalitesini nasıl algıladıklarını, algılanan kalitenin müşteri memnuniyeti ve değiştirme maliyetleri üzerindeki, müşteri memnuniyetinin değiştirme maliyetleri ve değiştirme maliyetlerinin de davranışsal niyetleri üzerindeki etkisini tespit etme amacını taşımaktadır.

Yöntem- Balıkesir il merkezi ve ilçelerindeki muhasebe meslek mensuplarından hizmet satın alan 1.070 gelir vergisi mükellefine ilgili literatürden yararlanılarak oluşturulan anket uygulanmış, elde edilen veriler istatistiksel analizlere tabi tutulmuş ve yorumlanmıştır.

Bulgular- Araştırma sonuçlarına göre, algılanan kalite müşteri memnuniyeti ve değiştirme maliyetleri üzerinde, müşteri memnuniyeti de değiştirme maliyetleri üzerinde anlamlı bir etkiye sahiptir. Değiştirme maliyetinin tüm boyutlarının davranışsal niyetlerin başkalarına öneride bulunma boyutu üzerinde anlamlı bir etkiye sahip olduğu, değiştirme maliyetlerinin finansal maliyet boyutunun ise davranışsal niyetlerin yeniden satın alma boyutu üzerinde etkiye sahip olmadığı tespit edilmiştir.

Sonuç- Araştırma sonucunda literatürler uyumlu olarak kalitenin müşteri memnuniyeti üzerinde etkili olduğu, işletmeler ile muhasebe meslek mensupları arasındaki ilişkide değiştirme maliyetlerinin yüksek olduğu belirlenmiştir. Ayrıca değiştirme maliyetleri boyutlarının davranışsal niyet boyutları üzerinde etkisi tespit edilmiştir.

Anahtar Kelimeler: Muhasebe meslek mensupları, hizmet kalitesi, müşteri memnuniyeti, değiştirme maliyetleri, davranışsal niyetler JEL Kodları: M41, M31, M37

\footnotetext{
${ }^{1}$ Bu çalışma 24-25 Mayıs 2017 tarihinde İstanbul'da gerçekleştirilen “Global Business Research Congress “de sunulan bildirinin genişletilmiş halidir. Balıkesir Üniversitesi Bilimsel Araştırma Projeleri Birimi (BAP) tarafından desteklenmiştir. Teşekkür ederiz.
} 


\section{GiRiş}

Günümüzde yaşanan yoğun rekabet, tüm işletmeler açısından kaliteli ürün/hizmet sunumunu zorunlu kılmaktadır. Işletmeler açısından kaliteli ürün/hizmet sunumu için muhasebe sürecinden elde edilen mali veriler son derece önemlidir. İşletmeler muhasebe sürecinden elde edilen bu mali verileri ya kendi organizasyonları içinde yer alan muhasebe birimlerinden, ya da bağımsız çalışan Serbest Muhasebeci ve Mali Müşavirlik bürolarından hizmet alımı yoluyla elde edebilirler. Ülkemizde, özellikle mikro ölçekli ve küçük ölçekli işletmeler, ihtiyaç duydukları mali verileri bağımsız çalışan Serbest Muhasebeci ve Mali Müşavirlik bürolarından hizmet alımı yoluyla elde etmektedirler. Bu açıdan bakıldığında, kendileri de bir işletme olan muhasebe meslek mensupları, kendi işletmeleri açısından hizmet kalitesi ve müşteri memnuniyetine özen göstermeleri gerektiği kadar, hizmet verdikleri işletmelerin hizmet kalitesi ve müşteri memnuniyetleri üzerinde de etkili olmaktadırlar. İşletmeler, muhasebe hizmetleri vasıtasıyla işletmelerinin finansal durumu ile ilgili en doğru ve güvenilir bilgilere ulaşabilecek ve işletmenin taraflarına bu bilgiler sunulacaktır. Bu nedenle muhasebe meslek mensupları, hizmet verdikleri işletmelerle ilgili doğru, anlaşılabilir, karşılaştırılabilir, kolay erişilebilir ve zamanında bilgiler sunmak zorundadır. Özetle, muhasebe meslek mensuplarının verdiği hizmetin kalitesi, hizmet alan işletmeler için önemlidir.

Açıklanan nedenlerle, muhasebe meslek mensupları için hizmet kalitesinin ölçülmesi ve müşteri memnuniyetinin belirlenmesi gerekmektedir. Bu durum müşteri sadakatinin belirlenmesi açısında da son derece önemlidir.

Literatürde, muhasebe meslek mensuplarınca verilen hizmetin kalitesini, müşteri memnuniyetini ölçen veya bunlar arasındaki ilişkiyi belirlemeye yönelik çalışmalar mevcuttur. Ancak, yapılan literatür araştırması kapsamında, muhasebe meslek mensuplarından hizmet satın alan işletmelerin algıladıkları hizmet kalitesi, müşteri memnuniyeti, değiştirme maliyetleri ve davranışsal niyetlerinin bir arada incelendiği çalışmaya rastlanmamıştır. Bu değişkenlerin bir arada incelenmesi bu çalışmanın özgün tarafını oluşturmaktadır.

\section{LITERATÜR TARAMASI}

\subsection{Hizmet Kalitesi}

Kalite, müşteri ihtiyaçlarını karşılayan ve böylece müşteri memnuniyetini sağlayan ürün özellikleri anlamına gelir (Juran \& Godfrey, 1999). Kalite, bir ürünün sahip olduğu üstünlük veya mükemmellik olarak tanımlanırken, algılanan kalite ise, ürünün mükemmelliğine veya üstünlüğüne yönelik tüketici değerlendirmesi (yargılaması) olarak tanımlanır (Zeithaml, 1988). Kalite, müşteri memnuniyeti, kâr ve ekonomik büyüme için önemli bir faktördür (Deming \& Edwards, 1982; Kennedy, 1987; Rust vd., 1995). Kalite sadece ürünlerde değil, müşteriler için sunulan hizmette de aranır.

Hizmet kalitesi, müşterilerin algıları ile beklentilerini karşılaştıran süreci değerlendiren bir sonuçtur. (Grönross, 1984). Hizmet kalitesi, bir işletmenin ve onun sunduğu hizmetlerin tüketicilerde bıraktığı genel izlenim diye tanımlanabilmektedir (Hank \& Baek, 2004:208). Parasuraman vd. $(1985,1988)$ hizmet kalitesini, müşterilerin bir hizmete ilişkin beklentileri ile yararlandığı gerçek hizmet deneyimindeki algısı arasındaki fark olarak açıklamışlardır. Cronin \& Taylor (1992, 1994) hizmet kalitesinin sadece algılanan hizmeti kullanarak ölçülmesi gerektiğini savunarak, hizmet kalitesini, müşteri memnuniyeti ve satın alma niyeti arasındaki ilişki ile açıklanmaya çalışmışlardır. Kalite açısından esas belirleyici unsur tüketicinin hizmetten beklentisidir (Küçükaltın, 2007). Hizmet kalitesi müşterinin firmada kalmasını, rekabet yeteneği gibi firmaya stratejik kazançlar ve uzun dönem karlılık sağlayan önemli bir kavramdır (Mpinganjira, 2015).

Literatürde hizmet kalitesini ölçmek için geliştirilen iki model ön plana çıkmaktadır. Bunlar Parasuraman vd. (1988) tarafından geliştirilen SERVQUAL yöntemi ve Cronin \& Taylor (1992)'ın ortaya attığı SERVPERF yöntemidir.

\subsection{Müşteri Memnuniyeti}

Müşteri memnuniyeti, müşterinin bir mal veya hizmetten umduğu yada beklediğini elde etmenin verdiği iyi hissetme veya hoşnutluğu ifade eden psikolojik bir kavramdır (Pizam \& Ellis, 1999:327). Oliver (1997:13), müşteri memnuniyetini; bir mal veya hizmetin bir özelliğinden veya hizmetin bütün olarak kendisinden, tüketimle ilgili keyif verici tatminkârlık olarak ifade etmektedir (Mohammad \& Alhamadani, 2011: 63).

Müşteriler, satın aldıkları ürün ve hizmetlere yönelik çeşitli beklentilere sahiptir (Hubbert vd., 1995: 7; Wall \& Berry, 2007 : 62). Müşteri memnuniyeti, tüketicinin alım sonrası elde ettikleri ile beklentilerini karşılaştırdığında ortaya çıkan olumlu durumdur (Peter \& Olson, 2010). Müşteriler açısından satın alınan ürün ve hizmetlerde beklentilerin karşılanması, onların memnuniyetini arttıran en önemli uygulamadır (Parasuraman vd., 1988).

Işletmelerin uzun dönem rekabet avantajı sağlamalarında ve amaçlarına ulaşmalarında müşteri memnuniyeti önemli bir rol üstlenmiştir (Henning-Thurau \& Klee, 1997).

\subsection{Değiştirme Maliyetleri}

Değiştirme maliyeti, herhangi bir malı veya hizmeti satın alan tarafından var olan işlemlerden kaynaklı ilişkileri sona erdirmek veya yeni bir ilişki başlatabilmek amacıyla katlanılan maliyetlerdir (Oyeniyi \& Abiodun, 2009:112). Porter (2007) 
değiştirme maliyetini, bir müşterinin hizmet aldığı bir firmadan başka bir firmaya geçmesi sonucu karşılaştığı maliyetler olarak ifade etmektedir. Bu maliyetler, sadece ekonomik değil aynı zamanda müşterinin yeni bir işletmenin müşterisi olmasından kaynaklanan psikolojik maliyetleri, yeni ürün ya da hizmet satın alma çabası ve zaman boyutunu da içermektedir (Klemperer, 1987; Klemperer,1995; Beatty vd., 2000; Jones vd., 2002; Kim vd., 2003; Yang \& Peterson, 2004; Wang, 2010).

Literatürde çok boyutlu olarak ölçülmüş olan (Klemperer, 1987; Jones vd., 2007; Meng \& Elliot, 2009) değiştirme maliyetleri Burnham vd. (2003) tarafından prosedürel maliyet, finansal maliyet ve ilişkisel maliyet şeklinde boyutlandırılmıştır.

Müşteriler, satın aldıkları bir üründen memnun olmadıkları ve beklentilerinin karşılanmadığı durumlarda ya şikayet etmekte ya da ürün satın aldığı firmayı değiştirmektedir (Anderson \& Sullivan, 1993). Bu durumda değiştirme maliyetleri önem arz etmektedir. Tüketiciler, mal veya hizmet satın aldıkları firmayı değiştirmek istediklerinde, kazanacaklarını ve katlanacakları maliyetleri değerlendirerek kararlarını verirler. Eğer elde edecekleri kazanç değiştirme maliyetinden yüksek ise müşterisi olduğu firmayı değiştirmeye karar verecekler, aksi durumda mevcut firma ile çalışmaya devam edeceklerdir.

Değiştirme maliyetleri, sektörden sektöre ve piyasa yapısına göre farklılık göstermektedir. Değiştirme maliyetinin düşük olduğu ve ürün veya marka alternatifinin çok olduğu sektörlerde, müşteriler sunulan hizmetin kalitesinden memnun kalmadığında rahatlıkla rakip işletmenin mal veya hizmetini tercih edebilmektedir. Bu tip sektörlerde de sadık müşteri elde etmek zorlaşmaktadır (Lee vd., 2001:38). Değiştirme maliyetleri arttıkça tüketicilerin hizmet satın aldığı firmayı değiştirme isteği azalacaktır (Aydın \& Özer, 2005).

\subsection{Davranışsal Niyetler}

Davranışsal niyetler, tüketicinin gelecekte aynı ürün veya hizmeti tekrar talep edip etmeyeceğini gösteren davranışlar bütünüdür (Yang vd., 2011).Davranışsal niyet, müşterilerin firmadan hizmet almaya devam edeceklerinin veya firmayı terk edeceklerinin bir göstergesidir (Lin \& Hiesh, 2005).

Smith vd., (1999) davranışsal niyetleri; ekonomik ve sosyal davranışlar olarak iki grupta incelerken, Cronin vd., (2000) ise davranışsal niyetleri; işletmeye sadık kalma, başkalarına olumlu tavsiyelerde bulunma, işletmeye daha fazla para harcama olarak üç madde ile daha geniş olarak incelenmiştir.

\subsection{Muhasebe Meslek Mensupları ile İlgili Hizmet Kalitesi, Müşteri Memnuniyeti, Değiştirme Maliyetleri ve Davranışsal Niyetler ile İlgili Literatür Taraması}

Literatürde, muhasebe meslek mensuplarınca ve denetim firmalarınca verilen hizmetin kalitesini, müşteri memnuniyetini, değiştirme maliyetlerini ve davranışsal niyetleri ölçen veya bunlar arasındaki ilişkiyi belirlemeye yönelik çalışmalar mevcuttur.

Higgins \& Ferguson (1991), hizmet kalitesi boyutlarının muhasebe hizmetleri üzerine nasıl uygulandığını analiz etmişler, hizmet kalitesini arttırmak için muhasebe firmalarına yönelik öneriler getirmişlerdir.

Armstrong \& Smith (1996), muhasebe firmalarının müşteriler tarafından seçilmesini etkileyen pazarlama faktörlerini ve bu pazarlama faktörleri ile müşterilerin hizmet kalitesi algıları arasındaki ilişkiyi analiz etmişlerdir. Bu çalışmada, muhasebe firmalarının müşteriler tarafından seçilmesini etkileyen pazarlama faktörlerinin; ücretler, fiziki olanaklar, firmanın itibarı, çalışanların davranışı kalitesi, firmanın deneyimi, arkadaş fikirleri gibi iç ve dış faktörler olduğu belirtilmiştir.

Keng \& Liu (1998), Parasuraman tarafından geliştirilen SERVQUAL ölçeğini uyarlayarak yaptıkları çalışmada Singapur, Japonya, Avrupa ve ABD'deki firmaların neden beş büyük denetim firmasını (Ernst\&Young, Coopers\&Lybrand, Price Waterhouse, Peat Marwick ve Deloitte\&Touche) seçtiklerini, denetim şirketlerinin performanslarını ve bu performanslar ile müşteri beklentileri arasındaki farklılıkları tespit etmişlerdir. Çalışmada, firmaların büyük denetim firmalarını seçmesinde en önemli etkenin firmanın itibarı olduğu, bunu ücretin ve firmanın uzmanlığının izlediği tespit edilmiştir.

Morton \& Scott (2007), Avustralya'daki denetim şirketlerinin hizmet kalitesini ölçmek ve müşterilerinin ek hizmetler alma niyetlerine hizmet kalitesi algılamalarının etkisini değerlendirmek amacıyla yaptıkları çalışmada, hizmet kalitesiyle müşteri tutma arasında düşük bir ilişki olduğunu tespit etmişler, bu durumu denetim firması değiştirmenin pahalı olmasına bağlamışlardır. Bu çalışmada hizmet kalitesi ile diğer potansiyel müşterilere tavsiye etme arasında ise bir ilişki bulunduğu, ağızdan ağıza tavsiyenin önemli bir tanıtım aracı olduğu sonucuna varılmıştır.

Ustaahmetoğlu vd. (2013), Rize'deki muhasebe hizmetini dışarıdan satın alan 65 vergi mükellefi ile yaptıkları çalışmada, muhasebe hizmeti satın alan müşterilerin algıladıkları hizmet kalitesi ile bekledikleri hizmet kalitesi arasında bazı farklılıklar bulunduğu, muhasebe hizmeti satın alan müşterilerin kendilerine sunulan hizmetin kalitesini fiziksel boyutta beklentilerinin üzerinde algılarken güvenilirlik, heveslilik, güven ve empati boyutlarında beklenen hizmet kalitesi ile algılanan hizmet kalitesi arasında anlamlı farklııklar olmadığı tespitinde bulunmuşlardır.

Yıldız vd. (2013), Kocaeli'nde faaliyet gösteren 1253 Kurumlar Vergisi mükellefi işletme üzerinde anket yöntemi ile yaptıkları çalışmada, muhasebecilerini değiştirme ile hizmet kalitesinin güvenilirlik, güven, heveslilik ve empati boyutları arasında 
anlamlı bir ilişki bulunduğu, fiziksel özellikler boyutu arasında ise anlamlı bir ilişki bulunmadığı sonucuna varmışlardır. Çalışmada mükelleflerin, muhasebecilerini değiştirip değiştiremeyeceklerine karar verirken uygun araç, büronun genel görünüşü, çalışanların giyimi gibi fiziksel özellikleri göz ardı ettikleri tespitinde bulunulmuştur.

Banar \& Ekergil (2010), Eskişehir il merkezinde faaliyet gösteren ve muhasebe hizmetlerini Serbest Muhasebeci ve Serbest Muhasebeci Mali Müşavir'lerden satın alan 269 işletme üzerinde anket yöntemiyle yaptıkları çalışmalarında, muhasebe meslek mensuplarının müşteri memnuniyetini etkileyen hizmet kalitesi boyutlarının "güvenilirlik", "empati" ve "fiziksel özellikler" olduğu tespitinde bulunmuşlardır.

Ustaahmetoğlu \& Savcı (2011), muhasebe bürolarında sunulan hizmetlerinin algılanan ve beklenen hizmet kalitesi arasındaki boşluğun muhasebeciler tarafından nasıl algılandığını belirlemek amacıyla yaptıkları çalışmada, muhasebe meslek mensuplarının hizmet kalitesi algılama ve beklentilerinin heveslilik ve empati boyutlarında farklılık gösterdiği, buna karşın fiziksel özellikler, güvenirlilik ve güven boyutlarında bir farklıık bulunmadığı belirtilmiştir.

Türk (2009), denetim firması müşterisi olan işletmelerin algıladıkları hizmet kalitesinin, müşteri tatmini ve sadakati üzerindeki etkilerini tespit etmeyi amaçlayan çalışmada, denetim firması müşterilerinin algıladıkları hizmet kalitesinin müşteri tatminini anlamlı ve pozitif olarak etkilediği, tatminin ise sadakati anlamlı ve pozitif yönde etkilediği tespiti yapılmıştır. Çalışmada ayrıca algılanan kalitenin doğrudan sadakati etkileyip etkilemediği de araştırımış ve test sonuçlarına göre, algılanan kalitenin doğrudan sadakati anlamlı ve pozitif yönde etkilediği tespiti yapılmıştır.

Yanık vd. (2012), tarafından yapılan çalışmada, Kocaeli ilinde çalışan muhasebe meslek mensuplarının ideal hizmet kalitesi ve mevcut hizmet kalitesi algıları SERVQUAL ölçeği ile araştııılmış, çalışma sonucuna göre, muhasebe meslek çalışanlarının ideal fiziksel, güvenilirlik ve empati algılayışları ile mevcut fiziksel, güvenilirlik ve empati algılayışları arasında istatistiksel olarak anlamlı bir fark olduğu tespit edilmiştir.

Yayla \& Cengiz (2006), muhasebe bürolarının kalite artırma çabalarında önemli olan kalite faktörlerinin önem düzeyini ve bir bütün olarak kalitenin müşteri memnuniyetine olan etkisini belirleyen genel bir model geliştirmek amacıyla yaptıkları çalışmada, hizmet kalitesi boyutlarından fiziksel özelliklerin, güvenlik, heveslilik, güvence ve empati boyutlarının algılanan kaliteyi olumlu yönde etkilediği, algılanan kalitenin de müşteri memnuniyetini olumlu yönde etkilediği tespitinde bulunmuşlardır.

Saxby vd. (2004), muhasebe hizmeti satın alan 154 işletme üzerinde yaptığı çalışmada hizmet kalitesi boyutlarından güvenilirlik ve güvenlik boyutlarının müşteri tatmini ile anlamlı ilişki içerisinde olduğu sonucuna varmış, fiziksel özellikler, heveslilik ve sempati boyutlarının ise müşteri tatmini ile anlamlı ilişki tespit edememiştir. Çalışmada, muhasebe hizmeti alan işletmeler açısından güvenilirliğin en önemli unsur olduğu, güvenilirlik içerisinde de doğruluk (kayıtların ve işlemlerin doğruluğu) unsurunun en önemli bileşen olduğu vurgulanmıştır.

Koç \& Şahin (2015), muhasebe hizmeti satın alan 405 küçük işletme üzerinde yaptıkları çalışmada, algılan hizmet kalitesinin değiştirme maliyetinin tüm boyutları üzerinde pozitif etkiye sahip olduğu, değiştirme maliyetinin prosedürel ve ilişkisel maliyet boyutlarının davranışsal niyetler üzerinde pozitif etkiye sahipken, finansal maliyet boyutunun ise herhangi bir etkiye sahip olmadığı sonucuna ulaşmışlardır.

\section{ARAŞTIRMANIN AMACI, VERI VE YÖNTEM}

Bu bölümde araştırmanın amacı, araştırmanın hipotezleri ve modeli, araştırmanın evreni ve örneklem ile anket formunun tasarımı açıklanmaktadır.

\subsection{Araştırmanın Amacı}

Bu araştırmanın amacı, muhasebe meslek mensuplarından hizmet satın alan beyannameli gelir vergisi mükelleflerinin satın aldıkları hizmetin kalitesini nasıl algıladıklarını, algılanan kalitenin müşteri memnuniyeti ve değiştirme maliyetleri üzerindeki, müşteri memnuniyetinin değiştirme maliyetleri ve değiştirme maliyetlerinin de davranışsal niyetleri üzerindeki etkisini tespit etmektir.

\subsection{Araştırmanın Hipotezleri ve Modeli}

Çalışmanın amacını ifade eden model Şekil 1'de sunulmuştur. 


\section{Şekil 1: Araştırmanın Modeli}

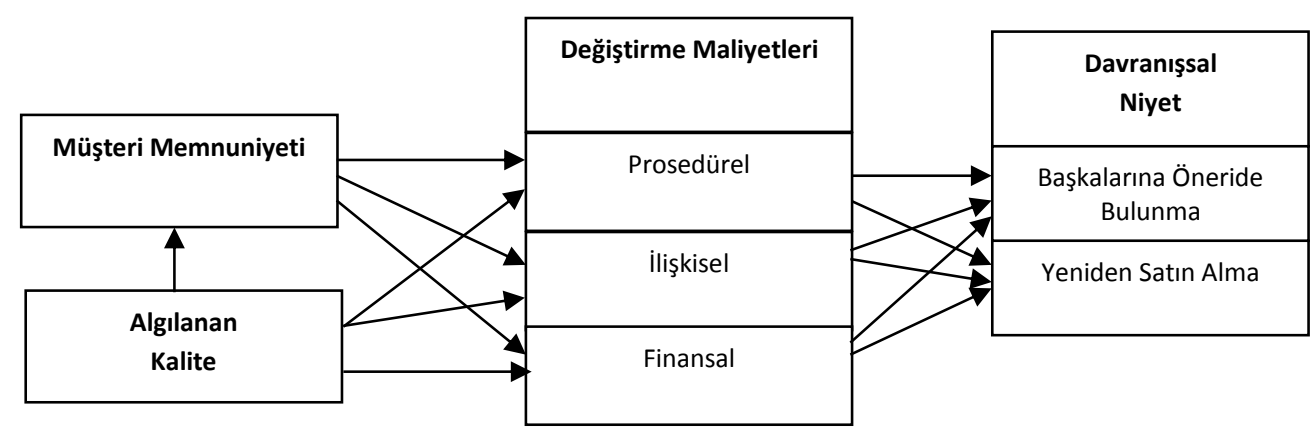

H1: Algılanan hizmet kalitesinin memnuniyet üzerinde anlamlı ve pozitif bir etkisi vardır.

H2: Algılanan hizmet kalitesinin prosedürel maliyet üzerinde anlamlı ve pozitif bir etkisi vardır.

H3: Algılanan hizmet kalitesinin ilişkisel maliyet üzerinde anlamlı ve pozitif bir etkisi vardır.

H4: Algılanan hizmet kalitesinin finansal maliyet üzerinde anlamlı ve pozitif bir etkisi vardır.

H5: Memnuniyetin prosedürel maliyet üzerinde anlamlı ve pozitif bir etkisi vardır.

H6: Memnuniyetin ilişkisel maliyet üzerinde anlamlı ve pozitif bir etkisi vardır.

H7: Memnuniyetin finansal maliyet üzerinde anlamlı ve pozitif bir etkisi vardır.

H8: Prosedürel maliyetin başkalarına önerme niyeti üzerinde anlamlı ve pozitif bir etkisi vardır.

H9: iliş̧kisel maliyetin başkalarına önerme niyeti üzerinde anlamlı ve pozitif bir etkisi vardır.

H10: Finansal maliyetin başkalarına önerme niyeti üzerinde anlamlı ve pozitif bir etkisi vardır.

H11: Prosedürel maliyetin yeniden satın alma niyeti üzerinde anlamlı ve pozitif bir etkisi vardır.

H12: iliş̧kisel maliyetin yeniden satın alma niyeti üzerinde anlamlı ve pozitif bir etkisi vardır.

H13: Finansal maliyetin yeniden satın alma niyeti üzerinde anlamlı ve pozitif bir etkisi vardır.

\subsection{Araștırmanın Evreni, Örneklem ve Anket Formunun Tasarımı}

Bu araştırmada, Balıkesir ili merkez (Balıkesir merkez olarak ifade edilen bölüm Altıeylül ve Karesi olmak üzere 2 ilçeden oluşmuştur) ve 18 ilçesinde bulunan ve muhasebe hizmetini dışarıdan satın alan gerçek usulde vergilendirilen gelir vergisi mükellefi olan (ticari kazanç ve serbest meslek kazancı elde eden) işletme sahipleri ana kütle olarak belirlenmiştir. Gelir İdaresi Başkanlığı (GIB) istatistiklerine göre Balıkesir ilindeki gerçek usulde vergilendirilen gelir vergisi mükellefleri sayısı araştırmanın başladığı Kasım 2016 tarihi itibariyle 28.002'dir. Bu sayının içerisinde TÜRMOB kayıtlarına göre sayısı 643 olan bağımsız çalışan Serbest Muhasebeci Mali Müşavirler de dâhildir. Araştırma muhasebe meslek mensuplarının verdiği hizmetin kalitesinin ve müşteri memnuniyetinin değerlendirilmesi olduğu için, meslek mensupları kapsam dışında bırakıldığında, araştırmanın ana kütlesi (28.002 - 643 =) 27.359'dur.

Araştırmada veri toplama aracı olarak anket yöntemi kullanılmıştır. Anket uygulaması için kolayda örnekleme metodu seçilmiş ve uygulama yüz yüze yapılarak gerçekleştirilmiştir. Araştırma kapsamında 1.163 işletme sahibi ile görüşülmüştür. Eksik bilgi verilen 93 anket araştırmaya dahil edilmeyerek, 1.070 anket veri analizinde kullanılmıştır. Nüfus ve kapsam dahilindeki işletme sayısı az olan bazı ilçelerde hiç sonuç alınamamıştır.

Anket formu 5 bölümden oluşmaktadır. Birinci bölüm demografik faktörlerden, ikinci bölüm algılanan kalite ölçeğinden, üçüncü bölüm müşteri memnuniyeti ölçeğinden ve dördüncü bölüm değiştirme maliyeti ölçeğinden ve beşinci bölüm davranışsal niyetler ölçeğinden oluşmaktadır.

Araştırmada Koç vd. (2014) tarafından Swaen \& Chumpitaz (2008)'in çalışmasından alınarak kullanılan 3 sorudan oluşan Algılanan Kalite Ölçeği, Banar \& Ekergil (2010) tarafından Ishak vd. (2006) ile Saxby vd. (2004)'nin kullandıkları ölçeklerden yararlanılarak kullanılan 6 sorudan oluşan Müşteri Memnuniyeti Ölçeği kullanılmıştır. Araştırmada Koç \& Şahin (2015) tarafından Sharma (2003), Burnham vd. (2003), Jones vd. (2000) ve Vasudevan vd. (2006) çalışmalarından alınarak kullanılmış olan ve toplam 14 sorudan oluşan Değiştirme Maliyetleri Ölçeği kullanılmıştır. Davranışsal Niyetler Ölçeği Lam vd.(2004)'nin çalışmasından alınmış olup 5 sorudan oluşmaktadır. Ölçekler, (1) Kesinlikle Katılmıyorum, (2) Katıımıyorum, (3) Kararsızım, (4) Katılıyorum, (5) Kesinlikle Katılıyorum olmak üzere 5 basamaklı likert tipi puanlanmıştır.

Analizler SPSS 22.0 paket programı kullanılarak yapılmıştır. 


\section{BULGULAR}

\subsection{Demografik Faktörlere İlişkin Bulgular}

Aşağıdaki Tablo 1'de ankete katılan işletme sahiplerinin demografik özelliklerini gösteren frekans dağılımları görülmektedir.

Araştırmaya katılan işletmelerin, mevcut işlerini yapma sürelerinin ortalama 10,81 yıl olduğu görülmüştür. Araştırmaya katılan işletmelerin mevcut muhasebecileri ile çalışma ortalamaları ise 8,25 yıl olarak ifade edilmiştir.

Tablo 1: Demografik Özellikler

\begin{tabular}{lll}
\hline Cinsiyet & Frekans & Yüzde \\
\hline Kadın & 208 & 19,4 \\
Erkek & 862 & 80,6 \\
Toplam & 1070 & 100,0 \\
\hline İșletme Türü & Frekans & Yüzde \\
\hline Tek Şahıs & 965 & 90,2 \\
Adi Ortaklık & 105 & 9,8 \\
Toplam & 1070 & 100,0 \\
\hline Eğitim Durumu & Frekans & Yüzde \\
\hline ilkokul & 114 & 10,7 \\
Ortaokul & 208 & 19,4 \\
Lise & 489 & 45,7 \\
Ön Lisans & 121 & 11,3 \\
Lisans & 111 & 10,4 \\
Lisans Üstü & 27 & 2,5 \\
Toplam & 1070 & 100,0 \\
\hline Çalıșan Sayısı & Frekans & Yüzde \\
\hline Yok & 584 & 54,6 \\
1-9 & 467 & 43,6 \\
10-49 & 19 & 1,8 \\
Toplam & 1070 & 100,0 \\
\hline
\end{tabular}

\begin{tabular}{lll}
\hline Medeni Durum & Frekans & Yüzde \\
\hline Evli & 849 & 79,3 \\
Bekâr & 221 & 20,7 \\
Toplam & 1070 & 100,0 \\
\hline Mükellefiyet Türü & Frekans & Yüzde \\
\hline I.Sınıf Tacir & 401 & 37,5 \\
II.Sınıf Tacir & 640 & 59,8 \\
Serbest Meslek & 29 & 2,7 \\
Toplam & 1070 & 100,0 \\
& & \\
& & \\
\hline Mevcut SMMM ile & Frekans & Yüzde \\
Çalıșma Süresi & & \\
\hline $1-5$ Yıl & 489 & 45,7 \\
6-10 Yıl & 297 & 27,8 \\
11-15 Yıl & 128 & 12,0 \\
16-20 Yıl & 89 & 8,3 \\
$21-25$ Yıl & 38 & 3,6 \\
26 ve Üzeri & 29 & 2,7 \\
Toplam & 1070 & 100,0 \\
& & \\
\hline
\end{tabular}

\begin{tabular}{lll}
\hline Yaș & Frekans & Yüzde \\
\hline 24 ve Altı & 56 & 5,2 \\
$25-30$ & 207 & 19,3 \\
$31-35$ & 171 & 16,0 \\
$36-40$ & 214 & 20,0 \\
$41-45$ & 165 & 15,4 \\
$46-50$ & 116 & 10,8 \\
$51-55$ & 77 & 7,2 \\
$56-60$ & 42 & 3,9 \\
61 ve Üzeri & 22 & 2,1 \\
Toplam & 1070 & 100,0 \\
\hline Faaliyet & Frekans & Yüzde \\
\multicolumn{1}{c}{ Süresi } & & \\
\hline $1-5$ Yıl & 349 & 32,6 \\
$6-10$ Yıl & 300 & 28,0 \\
$11-15$ Yıl & 164 & 15,3 \\
$16-20$ Yıl & 121 & 11,3 \\
$21-25$ Yıl & 54 & 5,0 \\
26 ve Üzeri & 82 & 7,7 \\
Toplam & 1070 & 100,0 \\
& & \\
\hline
\end{tabular}

\subsection{Faktör Analizleri ve Güvenirlilik Testleri}

Araştırmada kullanılan ölçeklerin geçerlilikleri için yapılan açıklayıcı faktör analizleri ve güvenilirlik analizlerinin sonuçları aşağıdaki Tablo 2'de yer almaktadır.

Tablo 2: Açıklayıcı Faktör Analizi Ve Güvenilirlik Analizi Sonuçları

\begin{tabular}{|c|c|c|c|c|}
\hline Ölçekler & $\begin{array}{l}\text { Faktör } \\
\text { Yükleri }\end{array}$ & Özdeğer & $\begin{array}{c}\text { Açıklanan } \\
\text { Varyans (\%) }\end{array}$ & $\begin{array}{l}\text { Cronbach's } \\
\text { Alpha }\end{array}$ \\
\hline \multicolumn{5}{|l|}{ Müşteri Memnuniyeti } \\
\hline Genel olarak, muhasebecim benim işletmem için iyi şeyler yapar. & 0,770 & \multirow{6}{*}{10,169} & \multirow{6}{*}{36,318} & \multirow{6}{*}{0,877} \\
\hline Muhasebecimden genel olarak çok memnunum. & 0,762 & & & \\
\hline Muhasebecim genel olarak işini iyi yapar. & 0,750 & & & \\
\hline Şu anki muhasebecimle uzun yıllar çalışmayı sürdürmek isterim. & 0,736 & & & \\
\hline Muhasebecim çok dürüsttür. & 0,712 & & & \\
\hline Muhasebecimi, tanıdığım diğer işletmelere de öneririm. & 0,645 & & & \\
\hline \multicolumn{5}{|l|}{ Prosedürel Maliyet } \\
\hline $\begin{array}{l}\text { Eğer muhasebecimi değiştirirsem, yenisini bulmak için çok fazla } \\
\text { araştırma yapmak zorunda kalırım. }\end{array}$ & 0,751 & \multirow{5}{*}{3,303} & \multirow{5}{*}{11,795} & \multirow{5}{*}{0,839} \\
\hline $\begin{array}{l}\text { Yeni bir muhasebeci ile çalışmam, muhtemelen bazı sıkıntılarla } \\
\text { karşılaşmama neden olur. }\end{array}$ & 0,747 & & & \\
\hline $\begin{array}{l}\text { Muhasebecimi değiştirmem, benim için zaman ve çaba kaybı anlamına } \\
\text { gelir. }\end{array}$ & 0,700 & & & \\
\hline $\begin{array}{l}\text { Eğer muhasebecimi değiştirirsem, aynı kalitede hizmet alabileceğimden } \\
\text { emin değilim. }\end{array}$ & 0,671 & & & \\
\hline Yeni muhasebecinin iş yapma tarzı, bana uygun olmayabilir. & 0,663 & & & \\
\hline \multicolumn{5}{|l|}{ Finansal Maliyet } \\
\hline $\begin{array}{l}\text { Eski muhasebecimin bana ücretsiz verdiği hizmetler için, yeni } \\
\text { muhasebecim benden ekstra para isteyebilir. }\end{array}$ & 0,809 & \multirow[t]{2}{*}{1,369} & \multirow{2}{*}{4,888} & \multirow{2}{*}{0,839} \\
\hline $\begin{array}{l}\text { Eğer muhasebecimi değiştirirsem, yenisine daha fazla ücret ödemek } \\
\text { zorunda kalabilirim. }\end{array}$ & 0,797 & & & \\
\hline
\end{tabular}




\begin{tabular}{|c|c|c|c|c|}
\hline $\begin{array}{l}\text { Yeni bir muhasebeci ile çalışırsam, eski muhasebecimin bana sağladığı } \\
\text { bazı ayrıcalıkları kaybederim. }\end{array}$ & 0,729 & & & \\
\hline Yeni muhasebeciye geçmek bana bazı maliyetleri de beraberinde getirir. & 0,619 & & & \\
\hline \multicolumn{5}{|l|}{ ilişkisel Maliyet } \\
\hline Şu anki muhasebecim ve onun çalışanları, benim için önemli kişilerdir. & 0,724 & \multirow{5}{*}{1,318} & \multirow{5}{*}{4,706} & \multirow{5}{*}{0,801} \\
\hline Yeni bir muhasebeci ile iyi ilişkiler kurmam oldukça fazla zaman alır. & 0,648 & & & \\
\hline $\begin{array}{l}\text { Eğer muhasebecimi değiştirirsem, yeni muhasebecimle kuracağım ilişki, } \\
\text { eskisi kadar iyi gitmeyebilir. }\end{array}$ & 0,646 & & & \\
\hline $\begin{array}{l}\text { Yeni bir muhasebeciye geçmem, daha önce kurduğum iyi ilişkilerimi } \\
\text { bozar. }\end{array}$ & 0,563 & & & \\
\hline Şu anki muhasebecimle kurmuş olduğum ilişkiyi bozmak istemem. & 0,558 & & & \\
\hline \multicolumn{5}{|l|}{ Başkalarına Önerme } \\
\hline Muhasebecim hakkında çevremdekilere olumlu şeyler söylerim. & 0,766 & \multirow{3}{*}{1,047} & \multirow{3}{*}{3,739} & \multirow{3}{*}{0,875} \\
\hline $\begin{array}{l}\text { Yeni bir muhasebeci arayan kişilere, kendi muhasebecimle çalışmalarının } \\
\text { doğru bir karar olacağını söylerim. }\end{array}$ & 0,760 & & & \\
\hline Benden tavsiye isteyen diğer kişilere, muhasebecimi öneririm. & 0,745 & & & \\
\hline \multicolumn{5}{|l|}{ Algılanan Kalite } \\
\hline $\begin{array}{l}\text { Benim muhasebecimin sunduğu hizmetin kalitesi, diğer muhasebecilerle } \\
\text { karşılaştırdığımda, en iyisidir. }\end{array}$ & 0,779 & \multirow{3}{*}{1,030} & \multirow{3}{*}{3,678} & \multirow{3}{*}{0,832} \\
\hline Benim muhasebecimin sunduğu hizmet iyi kalitededir. & 0,678 & & & \\
\hline Muhasebecimin sunduğunu hizmetin kalitesinden asla şikâyet etmem. & 0,552 & & & \\
\hline \multicolumn{5}{|l|}{ Yeniden Satın Alma } \\
\hline Önümüzdeki yıllarda yine aynı muhasebeciyle çalışmayı düşünürüm. & 0,805 & \multirow{2}{*}{0,759} & \multirow{2}{*}{2,712} & \multirow{2}{*}{$*$} \\
\hline Simdiki muhasebecim her zaman benim ilk tercihimdir. & 0,712 & & & \\
\hline
\end{tabular}

Çıkarım metodu: Principal Component Analysis.

Döndürme Metodu: Varimax with Kaiser Normalization.

* Ölçek iki sorudan oluştuğu için alfa katsayısı hesaplanmamıştır.

Tablo 2 incelendiğinde algılanan kalite ölçeğinin 1, müşteri memnuniyeti ölçeğinin 1, değiştirme maliyeti ölçeğinin 3 ve davranışsal niyetler ölçeğinin 2 boyutlu olduğu ve literatüre uygun oldukları görülmüştür. Ayrıca, tüm faktör yükleri 0,50'nin üzerindedir. Ölçeğin güvenirliliği için alfa katsayıları hesaplanmıştır. Boyutların alfa katsayısı incelendiğinde, tümünün 0,80'nin üzerinde olduğu görülmektedir. Bu sonuç, ölçeğin yeterli düzeyde güvenilir olduğunu göstermektedir.

Ölçeklerin geçerlilik ve güvenilirliği sağlandıktan sonra, değişkenler arasındaki ilişkileri (korelasyon) ve bazı tanımlayıcı istatistikleri incelemek yerinde olacaktır. Bu amaçla aşağıdaki Tablo 3 hazırlanmıştır.

Tablo 3: Değişkenler Arasındaki iliş̧kiler ve Bazı Tanımlayıcı İstatistikler

\begin{tabular}{|c|c|c|c|c|c|c|c|c|}
\hline \multirow{2}{*}{ DEĞiŞKENLER } & \multicolumn{6}{|c|}{ Korelasyonlar } & \multicolumn{2}{|c|}{ Tanımlayıcı İstatistikler } \\
\hline & 1 & 2 & 3 & 4 & 5 & 6 & Ortalama & Std. Sapma \\
\hline (1) Finansal & & & & & & & 4,000 & 0,814 \\
\hline (2) ilişkisel & $0,598 * *$ & & & & & & 4,100 & 0,677 \\
\hline (3) Öneri & $0,404^{* *}$ & $0,471^{* *}$ & & & & & 4,253 & 0,721 \\
\hline (4) Satın Alma & $0,219 * *$ & $0,395 * *$ & $0,487 * *$ & & & & 4,298 & 0,710 \\
\hline (5) Memnuniyet & $0,283 * *$ & $0,429 * *$ & $0,613^{* *}$ & $0,539 * *$ & & & 4,333 & 0,598 \\
\hline (6) Kalite & $0,337^{* *}$ & $0,459 * *$ & $0,562^{* *}$ & $0,642 * *$ & $0,576 * *$ & & 4,162 & 0,731 \\
\hline (7) Prosedürel & $0,575^{* *}$ & $0,641 * *$ & $0,397^{* *}$ & $0,305^{* *}$ & $0,362 * *$ & $0,417^{* *}$ & 4,083 & 0,712 \\
\hline
\end{tabular}

**. Korelasyonlar 0,01 Düzeyinde Anlamlıdır

\subsection{Hipotezlerin Testi}

Araştırmanın modelinden hareketle geliştirilen hipotezlerin testi, regresyon analizi kullanılarak yapılmıştır. SPSS 22.0 paket programı aracılığıyla regresyon analizi gerçekleştirilmiştir. Analiz sonuçları Tablo 4'de sunulmuştur. 


\begin{tabular}{|c|c|c|c|c|c|c|c|c|c|c|c|c|}
\hline \multirow{4}{*}{$\begin{array}{c}\text { Bağımsız } \\
\text { Değişkenler }\end{array}$} & \multicolumn{12}{|c|}{ Bağımlı Değişkenler } \\
\hline & \multirow{2}{*}{\multicolumn{2}{|c|}{ Memnuniyet }} & \multicolumn{6}{|c|}{ Değiştirme Maliyetleri } & \multicolumn{4}{|c|}{ Davranışsal Niyet } \\
\hline & & & \multicolumn{2}{|c|}{ Prosedürel } & \multicolumn{2}{|c|}{ İlişkisel } & \multicolumn{2}{|c|}{ Finansal } & \multicolumn{2}{|c|}{ Önerme } & \multicolumn{2}{|c|}{ Satın alma } \\
\hline & $\beta$ & $\mathrm{P}$ & $\beta$ & $\mathrm{P}$ & $\beta$ & $\mathrm{P}$ & $\beta$ & $\mathrm{P}$ & $\beta$ & $\mathrm{P}$ & $\beta$ & $\mathrm{P}$ \\
\hline Kalite & 0,576 & 0,001 & 0,417 & 0,001 & 0,459 & 0,001 & 0,337 & 0,001 & & & & \\
\hline Model değerleri & \multicolumn{2}{|c|}{$\begin{array}{l}R^{2}=0,332 * \\
F=529,643\end{array}$} & \multicolumn{2}{|c|}{$\begin{array}{l}R^{2}=0,174 * \\
F=224,763\end{array}$} & \multicolumn{2}{|c|}{$\begin{array}{l}R^{2}=0,211^{*} \\
F=285,539\end{array}$} & \multicolumn{2}{|c|}{$\begin{array}{l}R^{2}=0,114^{*} \\
F=136,880\end{array}$} & & & & \\
\hline Memnuniyet & & & 0,362 & 0,001 & 0,429 & 0,001 & 0,283 & 0,001 & & & & \\
\hline Model değerleri & & & \multicolumn{2}{|c|}{$\begin{array}{l}R^{2}=0,131^{*} \\
F=161,402\end{array}$} & \multicolumn{2}{|c|}{$\begin{array}{l}R^{2}=0,184^{*} \\
F=240,681\end{array}$} & \multicolumn{2}{|c|}{$\begin{aligned} R^{2} & =0,080 * \\
F & =92,853\end{aligned}$} & & & & \\
\hline Prosedürsel & & & & & & & & & 0,111 & 0,002 & 0,107 & 0,005 \\
\hline İlişkisel & & & & & & & & & 0,306 & 0,001 & 0,361 & 0,001 \\
\hline $\begin{array}{l}\text { Finansal } \\
\text { Model Değerleri }\end{array}$ & & & & & & & & & $\begin{array}{r}0,157 \\
R^{2}=0 \\
F=11\end{array}$ & $\begin{array}{l}0,001 \\
251^{*} \\
9,315\end{array}$ & $\begin{array}{r}-0,059 \\
R^{2}=0 \\
F=6\end{array}$ & $\begin{array}{l}0,112 \\
162 * \\
822\end{array}$ \\
\hline
\end{tabular}

* Kurulan regresyon modeli 0,001 düzeyinde anlamlıdır.

Regresyon analizi modeldeki değişkenlerin yerlerine göre sırasıyla yapılmıştır. İlk olarak, kalitenin memnuniyet üzerindeki etkisi test edilmiştir. Yapılan analiz sonucunda, kalitenin memnuniyet üzerinde anlamlı ve pozitif bir etkisinin olduğu tespit edilmiştir ( $\beta=0,576 P=0,001)$. Bu sonuca göre, meslek mensubunun sunduğu hizmet kalitesinin müşteri memnuniyetini güçlü bir şekilde etkilediği söylenebilir. Sonuç olarak, H1 hipotezi desteklenmiştir.

Araştırma kapsamında ele alınan konulardan birisi de, kalitenin değiştirme maliyetleri üzerinde bir etkisinin olup olmadığını belirlemektir. Yapılan faktör analizi sonucunda, değiştirme maliyetinin üç boyutlu bir yapıya sahip olduğu görülmüştür. Kalitenin bu üç boyut üzerinde bir etkisinin olup olmadığının belirlenmesi için, kalitenin her bir boyutla olan ilişkisi ayrı bir regresyon modeli ile analiz edilmiştir. İlk olarak, kalitenin prosedürel maliyetle olan ilişkisi incelenmiştir. Yapılan analiz sonucunda, kalitenin prosedürel maliyeti pozitif etkilediği belirlenmiştir $(\beta=0,417, P=0,001)$. İinci analizde kalitenin ilişkisel maliyet üzerindeki etkisi tespit edilmeye çalışılmıştır. Analiz sonuçlarına göre, kalitenin ilişkisel maliyeti pozitif etkilediği sonucuna ulaşılmışır $(\beta=0,459, P=0,001)$. Son olarak, kalitenin finansal maliyet üzerindeki etkisi incelenmiş ve pozitif bir etkinin var olduğu belirlenmiştir $(\beta=0,337, P=0,001)$. Tüm bu sonuçlara göre $H 2, H 3$ ve $H 4$ hipotezleri desteklenmiştir. Sonuç olarak, meslek mensubunun sunduğu hizmet kalitesinin değiştirme maliyetlerini artırdığı söylenebilir.

Araştırmanın bir diğer inceleme konusu, memnuniyetin değiştirme maliyetleri üzerindeki etkisini belirlemektir. Bu etkiyi belirlemek için, memnuniyetin değiştirme maliyetlerinin her bir boyutu ilgili olarak regresyon modeli kurulmuştur. Yapılan analizler sonucunda, memnuniyetin prosedürel maliyet $(\beta=0,362, P=0,001)$, ilişkisel maliyet $(\beta=0,429, P=0,001)$ ve finansal maliyet $(\beta=0,283, P=0,001)$ üzerinde anlamlı ve pozitif etkili olduğu sonucuna ulaşılmıştır. Bu sonuçlara göre, $\mathrm{H} 5, \mathrm{H} 6 \mathrm{ve} \mathrm{H7}$ hipotezleri desteklenmiştir. Sonuç olarak, meslek mensupları müşteri memnuniyetini sağladığında, müşterilerin meslek mensubunu değiştirme maliyetleri artacaktır ve muhasebecisini değiştirmeyecektir.

Değiştirme maliyetlerinin davranışsal niyetler üzerindeki etkisi, bu çalışmanın bir diğer inceleme konusudur. Davranışsal niyetler literatürde tek boyutlu ve iki boyutlu olarak ele alınmıştır. Bu çalışmada yapılan faktör analizinde davranışsal niyetlerin, başkalarına hizmet satın aldığı muhasebeciyi önerme ve yeniden hizmet satın alma boyutlarından oluştuğu tespit edilmiştir. Değiştirme maliyetlerinin üç boyutunun önerme ve yeniden satın alma boyutları ile ayrı olarak regresyon analizi yapılmıştır. Yapılan analizler sonucunda prosedürel maliyet $(\beta=0,111, P=0,002)$, ilişkisel maliyet $(\beta=0,356, P=0,001)$ ve finansal maliyetin $(\beta=0,157, P=0,001)$ önerme boyutu üzerinde pozitif etkili olduğu tespit edilmiştir. Bu sonuçlara göre $H 8$, $\mathrm{H} 9$ ve $\mathrm{H} 10$ hipotezleri desteklenmiştir.

Değiştirme maliyetlerinin yeniden satın alma niyeti üzerindeki etkisini belirlemek için, ayrı bir regresyon modeli kurulmuştur. Yapılan analiz sonucunda prosedürel $(\beta=0,107, P=0,005)$ ve ilişkisel $(\beta=0,361, P=0,001)$ maliyetlerin yeniden satın alma niyeti üzerinde pozitif bir şekilde etkili olduğu tespit edilmiştir. Finansal maliyetin $(\beta=-0,059, P=0,112)$ ise yeniden satın alma niyeti üzerinde etkili olmadığı, yapılan analiz sonucunda belirlemiştir. Bu sonuçlara göre H11 ve H12 hipotezleri kabul edilirken, $\mathrm{H} 13$ hipotezi reddedilmiştir. 


\section{SONUÇ VE ÖNERILER}

Bu çalışma, muhasebe meslek mensuplarından hizmet satın alan gerçek usulde vergilendirilen gelir vergisi mükellefi (ticari kazanç ve serbest meslek kazancı elde eden) işletme sahiplerinin satın aldıkları hizmetin kalitesini nasıl algıladıklarını, algılanan kalitenin müşteri memnuniyeti ve değiştirme maliyetleri üzerindeki, müşteri memnuniyetinin değiştirme maliyetleri ve değiştirme maliyetlerinin de davranışsal niyetleri üzerindeki etkisini tespit etme amacıyla yapılmıştır.

Araştırmaya katılan işletmelerin mevcut işlerini yapma süreleri ortalamasının 10,81 yıl olduğu, mevcut muhasebecileri ile çalışma süreleri ortalamasının ise 8,25 yıl olduğu tespit edilmiştir. Muhasebe meslek mensuplarından hizmet satın alan gerçek usulde vergilendirilen gelir vergisi mükellefi (ticari kazanç ve serbest meslek kazancı elde eden) işletme sahiplerinin satın aldıkları hizmetlerle ilgili algıladıkları kalite ortalamasının 4,162 olduğu, müşteri memnuniyeti ortalamasının ise 4,333 olduğu görülmüştür. Bu durum, araştırmaya katılan işletmelerin muhasebe meslek mensuplarından satın aldıkları hizmetlere ilişkin beklentilerinin karşılandığını ve bu nedenle de kalitenin olumlu algılandığını, memnuniyet düzeylerinin de yüksek olduğunu göstermektedir.

Müşteriler açısından satın alınan ürün ve hizmetlerde beklentilerin karşılanması, onların memnuniyetini arttıran en önemli uygulamadır (Parasuraman vd., 1988). Çalışmada, literatürle uyumlu olarak (Saxby vd., 2004; Yayla \& Cengiz, 2006; Banar \& Ekergil, 2010; Yıldız vd., 2013), kalitenin müşteri memnuniyeti üzerinde etkili olduğu belirlenmiştir.

Araştırmaya katılan işletmelerin değiştirme maliyetleri boyutlarından prosedürel maliyet ortalamasının 4,083, ilişkisel maliyet ortalamasının 4,100 ve finansal maliyet ortalamasının 4,000 olduğu tespit edilmiştir. Bu durum, muhasebe meslek mensuplarından hizmet satın alan gerçek usulde vergilendirilen gelir vergisi mükellefi (ticari kazanç ve serbest meslek kazancı elde eden) işletmeler ile muhasebe meslek mensupları arasındaki ilişkide değiştirme maliyetlerinin yüksek olduğunu göstermektedir. Bu durum literatürdeki benze çalışmalarla (Koç vd., 2014; Koç \& Şahin, 2015) uyumludur. Yapılan analizlerde kalitenin değiştirme maliyetlerinin tüm boyutlarını pozitif etkilediği belirlenmiştir. Benze şekilde müşteri memnuniyetinin de değiştirme maliyetlerinin tüm boyutlarını pozitif etkilediği belirlenmiştir. Sonuç olarak, meslek mensubunun sunduğu hizmet kalitesinin değiştirme maliyetlerini artırdığı, meslek mensuplarının müşteri memnuniyetini sağladıklarında, müşterilerin meslek mensubunu değiştirme maliyetlerinin de artacağı ve muhasebecilerini değiştirmeyecekleri söylenebilir.

Araştırmaya katılan işletmelerin davranışsal niyetler boyutlarından başkalarına öneride bulunma boyutu ortalamasının 4,253 olduğu, yeniden satın alma ortalamasının ise 4,298 olduğu görülmüştür. Bu durum, araştırmaya katılan işletmelerin mevcut muhasebecilerinden hizmet almaya devam edecekleri ve mevcut muhasebecilerini başkalarına da önerecekleri konusunda güçlü bir görüşe sahip olduklarını göstermektedir. Değiştirme maliyetlerinin davranışsal niyetler üzerindeki etkisini belirlemek, bu çalışmanın bir diğer inceleme konusu olmuştur. Değiştirme maliyetlerinin üç boyutunun davranışsal niyetlerin başkalarına öneride bulunma ve yeniden satın alma boyutları ile ayrı olarak regresyon analizi yapılmıştır. Yapılan analizler sonucunda değiştirme maliyetleri boyutlarından prosedürel maliyet, ilişkisel maliyet ve finansal maliyetin başkalarına öneride bulunma boyutu üzerinde pozitif etkili olduğu, değiştirme maliyetleri boyutlarından prosedürel maliyet ve ilişkisel maliyet boyutlarının yeniden satın alma niyeti üzerinde de pozitif bir şekilde etkili olduğu, ancak değiştirme maliyetleri boyutlarından finansal maliyetin yeniden satın alma niyeti üzerinde etkili olmadığı belirlenmiştir. Bu durum değiştirme maliyetlerinin yüksek oluşunun davranışsal niyetleri de etkilediğini göstermektedir. Zira, değiştirme maliyetleri arttıkça tüketicilerin hizmet satın aldığı firmayı değiştirme isteği azalacaktır (Aydın \& Özer, 2005). Değiştirme maliyetleri boyutlarından finansal maliyetin yeniden satın alma niyeti üzerinde etkili olmaması, muhasebe hizmetlerinde ücret tarifesi bulunması ve bu nedenle benzer muhasebe hizmetleri için muhasebe meslek mensuplarına ödenecek ücrette çok fazla bir değişimin olmamasına bağlanabilir. Muhasebe meslek mensupları, hizmet verdikleri mükellef grubunun defterlerini tutmakta, beyanname ve bildirimlerini düzenlemekte, bu nedenle mükelleflerin başta mali idare olmak üzere kamuya olan mükellefiyetlerinin yerine getirilmesini sağlamaktadırlar. Bu yönüyle, meslek mensuplarından hizmet satın alan mükellefler açısından zamanında, doğru ve hatasız hizmet almak, herhangi bir cezai müeyyide ile karşılaşmamak açısından son derece önemli olup, bu durum muhasebe hizmeti karşılığında ödenecek ücretten çok daha öncelikli görülebilir.

Muhasebe meslek mensuplarınca kaliteli hizmet sunumu müşteri memnuniyeti ve değiştirme maliyetleri üzerinde etkili olmakta, değiştirme maliyetlerinin yüksekliği de müşterilerin davranışsal niyetlerini etkilemektedir. Bu çalışmada algılanan kalitenin ve müşteri memnuniyetinin doğrudan davranışsal niyetler üzerindeki etkisine yönelik bir analiz yapılmamış olup, bu konu gelecekte yapılacak araştırmalarda ele alınabilir.

Bu araştırma Balıkesir ilinde muhasebe meslek mensuplarından hizmet satın alan gerçek usulde vergilendirilen gelir vergisi mükellefi (ticari kazanç ve serbest meslek kazancı elde eden) işletme sahipleri üzerinde yapılmış olup, gelecekteki araştırmacılara farklı bölgelerdeki ve türdeki işletmeler üzerinde de benzer çalışmaların yapılması önerilebilir. 


\section{KAYNAKÇA}

Anderson, E.W., \& Sullivan, M.W. 1993, "Antecedents and Consequences of Customer Satisfaction For Firms", Marketing Sciences, 12 (2), pp.125-143.

Armstrong, R., \& Smith, M. 1996, "Marketing Cues and Perceptions of Service Quality in the Selection of Accounting Firms", Journal of Customer Service in Marketing \& Management, 2(2), pp. 37-59.

Aydın, S., \& Özer, G. 2005, "The Analysis of Antecedents of Customer Loyalty in The Turkish Mobile Telecommunication Market", European Journal of Marketing, 39, ss.910-925.

Banar, K., \& Ekergil, V. 2010, “Muhasebe Meslek Mensuplarının Hizmet Kalitesi: Sunulan Hizmetlerin Kalitesi ile Müşteri Memnuniyeti Iliş̧kisi Eskişehir Uygulaması", Anadolu Üniversitesi Sosyal Bilimler Dergisi, 10(1), ss.39-60.

Beatty, S. E., Jones, M. A., \& Mothersbaugh, D. V. 2000, "Switehing Bamers and Repurehase Intentions in Services", Journal of Retailing, Vol.76(2), pp.259-274,

Burnham, T.A., Freys, J.K., \& Mahajan, V. 2003, "Consumer Switching Costs: A Typology, Antecedents, and Consequences", Journal of Academy of Marketing Sciences, 31 (2), pp.109-126.

Cronin, J. J., \& Taylor, S. A. 1992, “Measuring Service Quality: A Reexamination and Extension”, The journal of Marketing, 56 (3), pp. 55-68.

Cronin, J. J., \& Taylor, S. A. 1994, "SERVPERF versus SERVQUAL: Reconciling Performance-Based and Perceptions-Minus-Expectations Measurement of Service Quality", Journal of Marketing, 58 (1), pp. 125-131.

Cronin, J. J., Brady, M. K., \& Hult, G. T. M. 2000, "Assessing the Effects of Quality, Value and Customer Satisfaction on Consumer Behavioral Intentions in Service Environments", Journal of Retailing, 76(2), pp.193-218.

Deming, W. E., \& Edwards, D. W. 1982, "Quality, productivity, and competitive position", Cambridge, MA: Massachusetts Institute of Technology. vol. 183.

Grönroos, C. 1984, “A Service Quality Model and Its Marketing Implications”, European Journal of Marketing, 18(4), pp.36-44.

Hank, S. L., \& Baek, S. 2004, “Antecedents and Consequences of Service Quality in Online Banking: An Application of The SERVQUAL Instrument", NA-Advances in Consumer Research, vol. 31, no. 1, pp.208-214.

Henning-Thurau, T. \& Klee, A. 1997, "The Impact Of Customer Satisfaction And Relationship Quality On Customer Retention: A Critical Reassesement And Model Development", Psychology \& Marketing, 14(18), pp.737-764.

Higgins, Lexis F., \& Ferguson, Jeffery M. 1991, "Practical Approaches for Evaluating the Quality Dimensions of Professional Accounting Services", Journal of Professional Services Marketing, 7(1), pp.3-17.

Hubbert, A., Sehorn R., Garcia A. \& Brown S. W. 1995, "Service Expectations: the Consumer Versus the Provider", International Journal of Service Industry Management, 6 (1), pp.6-21.

Ishak, I., Hasnah, H., Daing, N.I., \& Salmi, M.I. 2006, "Service Quality, Client Satisfaction and Loyalty Towards Audit Firms: Perceptions of Malaysian Public Listed Companies", Managerial Auditing Journal, 21(7), pp.738-756.

Jones, M. A., Motherbaugh, D.L.,\& Beatty, S.E. 2000, "Switching Barriers and Repurchase Intentions in Services", Journal of Retailing, 76(2), pp.259-274.

Jones, M. A., Beatty, S. E., \& Mothersbaugh, D. V. 2002, “Why Customers Stay: Measuring The Underlying Dimensions of Services Switehing Costs and Managing Their Differential Strategic Outcomes", Journal of Business Research, 55, pp.441-450.

Jones, M.A., Reynolds, K.E., Mothersbaugh, D.L., \& Beatty, S.E. 2007, "The Positive and Negative Effects of Switching Costs on Relational Outcomes", Journal of Service Research, Vol. 9 (4), pp.335-355.

Juran, J., \& Godfrey, A. B. 1999, "Quality Handbook" Republished McGraw-Hill.

Keng, K. A., \& Liu, P. 1998, "Expectation of Service Quality in Professional Accounting Firms: A Singapore Study", Journal of Customer Service in Marketing \& Management, 5(2), pp.39-54.

Kennedy, P.1987, "The Rise and Decline of Great Powers: Economic Change and Military Conflict from 1500-2000" New York.

Kim, M., Kliger, D., \& Vale, B. 2003, “Estirnating Switching Costs: The Case of Bankin”, Journal of Financial Intermediation, Article in Press.

Klemperer, P. 1987, "The Competitiveness of Markets With Switching Costs", Rand Joumal of Economies, vol. 18, no: 1, Spring, pp.138-150.

Klemperer, P. 1995, "Competition When Consumer Have Switching Costs: An Overview With Applications To Industrial Organization, Macroeconomics And Internataional Trade", Review of Economic Studies, 62, pp.515-539.

Koç, F., Şahin N.K.,\& Özbek, V. 2014, “Hizmet Hataları ve Algılanan Kalite Arasındaki Iliş̧i Üzerinde Değiştirme Maliyetinin Düzenleyici Etkisi: Küçük İşletmeler ve Hizmet Satın Aldıkları Muhasebecilere Yönelik Bir Uygulama”, Pazarlama ve Pazarlama Araştırmaları Dergisi, Sayı: 14, ss.21-46.

Koç, F., \& Şahin N.K. 2015, “Muhasebecilik Hizmetlerinde Değiştirme Maliyetleri”, İ̧̧letme Araştırmaları Dergisi, 7/2, ss.326-348. 
Küçükaltın, G. 2007, “Hizmet Kalitesi Kavramında Genel Bir Yaklaşım ve Hizmet Kalitesinin Önemi”, Editörler: Gümüşoğlu, Ş., Pınar, İ., Akan, P. ve Akbaba, A., Hizmet Kalitesi: Kavramlar, Yaklaşımlar ve Uygulamalar, Detay Yayıncılık, Ankara.

Lam, S. Y., Shankar, V., Erramilli, M. K., \& Murthy, B. 2004, "Customer Value, Satisfaction, Loyalty and Switching Costs: An Illustration From a Business-to-Business Service Context", Journal of The Academy of Marketing Science, 32(3), pp.293-311.

Lee, J., Lee, J., \& Feick, L. 2001, "The Impact of Switching Costs on the Customer Satisfaction Loyalty Link: Mobile Phone Service in France", Journal of Services Marketing, 15(1), pp.35-48.

Lin, J.S.C., \& Hsiech, P.L. 2005, "The Influence Of Technology Readiness On Satisfaction And Behavioral Intentions Toward Self-Service Technologies", Computers in Human Behavior, 23(3), pp.1597-1615.

Meng, J., \& Elliot, K.M. (2009). "Service Quality Dimensions: Antecedents of Consumer Switching Costs in Customer Relationships", International Journal of Business Strategy, 9(2), pp.128-135.

Mohammad, A. A. S., \& Alhamadani, S. Y. M. 2011, "Service Quality Perspectives and Customer Satisfaction in Commercial Banks Working in Jordan", Middle Eastern Finance and Economics, 14(1), pp.60-72.

Morton, A., \& Scott, D. R. 2007, "The association between perceived audit firm service quality and behavioural intentions", Journal of Contemporary Issues in Business \& Government, 13(2), pp.17-30.

Mpinganjira, M. 2015, “An Investigation Of Perceived Service Quality In Online Shopping: A Hierarchical Approach", The Journal of Applied Business Research, 31(1), pp.115-130.

Oliver, R. L. 1997, "Satisfaction: A Behavioral Perspective on the Consumer", Boston: McGraw-Hill

Oyeniyi, J. O., \& Abiodun, A. 2009, "Switching Cost and Customers Loyalty in the Mobile Phone Market: The Nigerian Experience", Business Intelligence Journal, 3(1), pp.111-121.

Parasuraman, A. Zeithalm, V.A. ;\& Berry, L. L. 1985, "A Conceptual Model of Service Quality and Its Implications for Future Research", Journal of Marketing, vol. 49, no.4, pp.41-50.

Parasuraman, A., Zeithaml, V. A., \& Berry, L. L. 1988, "Servqual: A Multiple-Item Scale for Measuring Customer Perceptions of Service Quality", Journal of Retailing, 64(1), pp.12-40.

Peter, J.P. \& Olson, J.C. 2010, “Consumer Behavior \& Marketing Strategy”, McGraw-Hill Irwin, 9.Edition.

Pizam, A., \& Ellis, T. 1999, "Customer Satisfaction and Its Measurement in Hospitality Enterprises", International Journal of Contemporary Hospitality Management, 11(7), pp.326-339.

Porter, M. 2007, "Rekabet Stratejisi: Sektör ve Rakip Analizi Teknikleri”, (Çev. Gülen Ulubilgen), Sistem Yayıncılık, İzmir.

Rust, R. T., Zahorik, A. J., \& Keiningham, T. L. 1995, "Return on quality (ROQ): Making service quality financially accountable", The Journal of Marketing, pp.58-70

Saxby, C. L., Ehlen, C. R., \& Koski, T. R. 2004, "Service quality in accounting firms: the relationship of service quality to client satisfaction and firm/client conflict", Journal of Business \& Economics Research (JBER), 2(11), pp.75-86.

Sharma, N. 2003, "The Role of Pure and Quasi-Moderators in Services: An Empiricallnvestigation of Ongoing Customer-Service-Provider Relationships", Journal of Retailing and Consumer Services, 10, pp.253-262.

Smith, A.K., Bolton, R.K., \& Wagner, J. 1999, "A Model of Customer Satisfaction with Service Encounters Involving Failure and Recovery", Journal of Marketing Research, vol. 34, pp.356-72.

Swaen, V., \& Chumpitaz, R. C. 2008, "Impact of Corporate Social Responsibility On Consumer Trust. Recherche et Applications en Marketing",, (English Edition), 23(4), pp.7-34.

Türk, Z. 2009, “Denetim Firmalarının Sunduğu Hizmet Kalitesi Müşteri Tatmini Ve Sadakati: Servperf Ölçeği”, Çukurova Üniversitesi Sosyal Bilimler Enstitüsü Dergisi, 18(1), ss.399-416.

Ustaahmetoğlu, E., \& Savcı, M. 2011, “Muhasebe Meslek Mensuplarının Sundukları Hizmetin Kalitesini Değerlendirmesi ve Örnek Bir Uygulama", Kocaeli Üniversitesi Sosyal Bilimler Enstitüsü Dergisi, 22(2), ss.168-184.

Ustaahmetoğlu, E., Aygün, D., \& Savcı, M. 2013, “Muhasebe Bürolarında Sunulan Hizmetin Kalitesinin Müşteriler Tarafından Değerlendirilmesine Yönelik Bir Uygulama", Uluslararası Yönetim iktisat ve Iş̧letme Dergisi, 9(18), ss.239-254.

Vasudevan, H., Gaur, S.S., \& Shinde, R.K. 2006, "Relational Switching Costs, Satisfaction and Commitment: A Study in The Indian Manufacturing Context", Asia Pacific Journal of Marketing and Logistics, 18(4), pp.342-353.

Wall, E. A., \& Berry, L. L. 2007, "The Combined Effects of the Physical Environment and Employee Behavior on Customer Perception of Restaurant Service Quality", Cornell Hotel and Restaurant Administration, 48 (1), 59-69.

Wang, C. 2010, Service Quality, "Perceived Value, Corporate Image and Customer Loyalty in the Context of Varying Levels of Switching Costs", Psychology \& Marketing, 27(3), pp.252-262. 
Yang, Z., \& Peterson, R. T. 2004, "Customer Perceived Value, Satisfaction and Loyalty: The Role of Switching Costs", Psychology \& Marketing, 21(10), pp.799-822.

Yang, J., Yingkang, G., \& Jian, C. 2011, “Festival Tourists'Emotion, Perceived Value, and Behavioral Intentions:A Test of the Moderating Effect of Festivalscape", Journal of Convention \& Event Tourism, 12: pp.25-44.

Yanık, A., Dinçel, G., Yıldız, F.,\& Karacan, S. 2012, "Muhasebe Meslek Mensuplarının İdeal Hizmet ve Mevcut Hizmet Kalitesi Algılarının Servqual Modeli ile Değerlendirilmesi", Mustafa Kemal Üniversitesi Sosyal Bilimler Enstitüsü Dergisi, 9(20), ss.593-604.

Yayla, H. E., \& Cengiz, E. 2006, “Muhasebe Bürolarında Algılanan Hizmet Kalitesi ve Mükelleflerin Tatmin Düzeylerine Yönelik Yapısal Bir Model Önerisi II", MUFAD Muhasebe ve Finansman Dergisi, 31, ss.175-184.

Yıldız, F., Dinçel, G., \& Yanık, A. 2013, "An Assessment of Account Service Quality from the Customer Perspective", European Journal of Scientific Research, vol.103, No:4, ss.598-609.

Zeithaml, V. A., 1988, "Consumer Perceptions of Price, Quality, and Value: A MeansEnd Model and Synthesis of Evidence", Journal of Marketing, 52 (July), pp.2-22. 